\title{
THE FORMATION OF Roches Moutonnées
}

\author{
SOME COMMENTS ON DR. H. CAROL'S ARTICLE \\ By W. V. Lewis (Cambridge)
}

DR. CAROL's observations are of great importance both because they throw light on a major problem of glacial erosion and because they afford direct evidence of extrusion or plastic flow occurring in a glacier. It is much to be hoped that Dr. Carol and others will produce further evidence on these lines, although the arduous and dangerous nature of the investigations may well deter all but the keenest glaciologists and most skilled climbers.

Roches moutonnées have received frequent reference in the literature, but it is doubtful if their significance has been fully appreciated. The contrast between their rounded contour on the upstream side and the steep jagged downstream face is always emphasized, but attention is rarely drawn to the fact that the drop on the downhill side is usually much greater than the rise on the

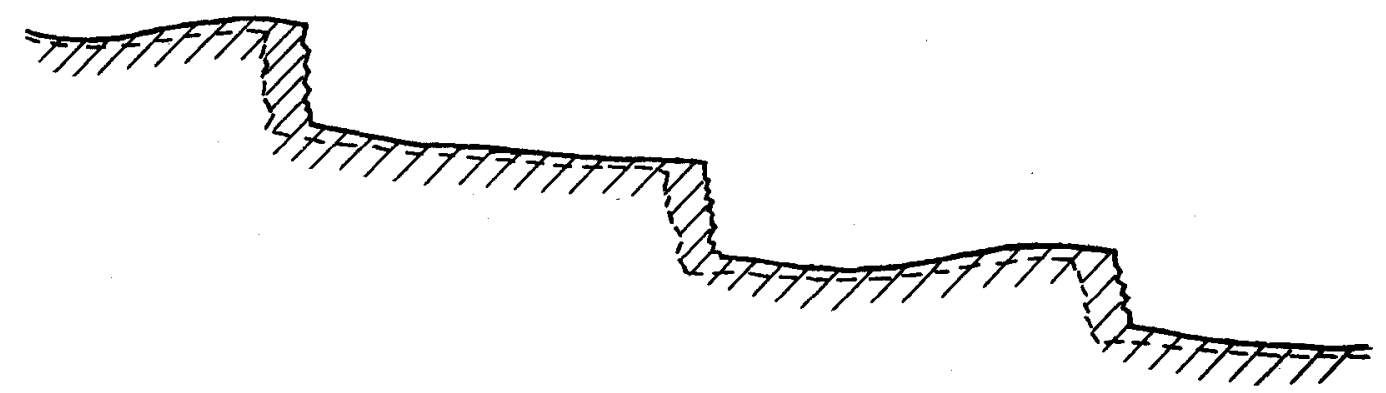

Fig. I. Long profile of a glaciated valley through a series of roches moutonnées.

uphillside. The major roches moutonnées form miniature steps on the valley floor revealing a long profile similar to that shown in Fig. I. Furthermore they vary much in size as well as in form. The cliffs of the larger ones may exceed $30 \mathrm{~m}$. in height and extend a considerable distance across the valley floor. In fact, every gradation can be found, from small roches moutonnées to steps which occupy the whole width of the valley floor.

If this strong family resemblance can be taken to indicate that there is something in common in their mode' of origin - and closer examination lends much support to this suggestion-then any light that can be thrown on the problem of the roches moutonnées may contribute to our knowledge of the formation of the glacial step. This in turn would contribute much towards an understanding of the nature of glacial erosion itself.

The roche moutonnée that Dr. Carol examined must have been at such a depth that the ice passing over it was subjected to a pressure just sufficient to cause plastic flow, whilst the ice immediately alongside was in a more rigid state. His explanation, which can be applied strictly to this one level, about $50 \mathrm{~m}$. below the surface of a glacier, therefore loses some of its appeal as one to account for features which are very widespread. Also we must beware of failing to attribute erosive power to ice moving at depth under extrusion flow, because in doing so we should be denying ice the ability to erode the deeply incised glacial valleys which undoubtedly occur. The Norwegian fjords provide perhaps the most striking evidence of the power of glaciers to erode deep valleys. Sogne Fjord, for instance, extends from $900 \mathrm{~m}$. or $\mathrm{I}, 200 \mathrm{~m}$. above, to $1,200 \mathrm{~m}$. below, sea-level, thus giving a total depth to the glacial trough of 2,000 to $2,400 \mathrm{~m}$. 
It is most revealing to trace the course of a valley tributary to the Sogne Fjord from its source high up on the Norwegian plateau down a series of steps to the fjord head. As an example, Styggedal in the Hurtungadn, forms a fairly deeply cut, U-shaped valley in the mountains and is occupied by a glacier which ends where this valley merges into a remnant of the neighbouring plateau region. Here, where the great Quaternary glaciers would not have been narrowly confined, there seemed to have been little downcutting. But where the ice from the Hurrungadn once joined ice from Fannaraaken the valley is more confined and plunges down a series of steps through Helgedalen and on past Turtagrö to Fortundalen, falling $1,200 \mathrm{~m}$. in six miles $\left(9^{\cdot 6 \mathrm{~km}}\right.$.). There can be no doubt about the erosive power of the agent which sculptured this valley and brought it to sea-level more than 100 miles $(160 \mathrm{~km}$.) from the open coast. Were this all, one would have considered the possibility of the valley having been formed by river action, as rivers have great erosive power on gradients of that order. Also the cross-section of the valley is V-shaped where the gradient is steep near Turtagrö. But Fortundalen leads straight into a tributary of Sogne Fjord and so merges into the great $U$-sectioned trough referred to above. River action could not have eroded this trough many thousands of feet below the level of the threshold or lip where the fjord enters the sea. Everything points to ice having been responsible, and if one concedes this point then one must accept the corollary that very thick glaciers, in which the ice in contact with the bed must be plastic, can yet accomplish a prodigious amount of erosion.

Matthes ${ }^{1}$ and Demorest ${ }^{2}$ take the reverse view to Carol. They welcome the extrusion flow hypothesis because it helps to account for the great erosion accomplished by thick glaciers. These authorities attribute the formation of glacial basins to the extra erosive power of the bottom ice, which moves by extrusion flow at a greater rate than the more rigid surface layers of ice.

This might not be a direct contradiction of Carol's hypothesis, for the latter was comparing the work of plastic ice with that of rigid ice moving over the rock bed with roughly similar velocities. Matthes, on the other hand, is comparing the erosive power of plastic ice moving at a relatively high velocity with ice in a similar-or possibly in the rigid state-moving more slowly.

Is all this deep erosion accomplished by thaw-freeze sapping or by grinding away of the rock bed which has already been somewhat rotted and weathered by long contact with the "wet" underside of the glacier? If one may hazard a guess, it seems that the answer should be that grinding and smoothing are mainly responsible. It is fairly well established that the temperature in glaciers below Io or $20 \mathrm{~m}$. from the surface is at the pressure melting point, that is, fractionally below $0^{\circ} \mathrm{C.} 3$ Great masses of ice at such a temperature must insulate the ground beneath against changes of temperature. Water may on occasion form at, or descend to, great depths. Pressure melting and the small transfer of heat from the interior of the earth may cause some water to form at depth. The latter source has been estimated as sufficient to melt a layer of ice about $6 \mathrm{~mm}$. thick each year. 4 But there is no mechanism at present known by which this water can freeze again provided there is complete insulation against atmospheric changes of temperature. It seems, therefore, that we must rule out thaw-freeze processes at great depth.

But this by no means rules out the possibility of thaw-freeze, to which Dr. Carol appeals, being of paramount importance at lesser depths. More material is probably removed from the rugged downstream side than from the smoothed upper side. A possible subsequent stage in the erosion of the roches moutonnées, shown in Fig. I, p. 60, is indicated by the broken line. Were the evolution otherwise, the roches moutonnées could not survive long under the glacier. Because if grinding away the upper side were the predominant form of erosion the features would soon be flattened out, whereas cliff recession would merely cause them to recede upstream whilst maintaining their identity. The frequency of their occurrence does, in fact, suggest that they are relatively long-lived and not merely transient forms under a glacier.

The example Carol cites was one in which the cliff face was exposed to the atmosphere and would therefore seem to represent an ideal case for thaw-freeze to be operative. In addition, the 
rock mass must have been subjected both to substantial hydrostatic pressure, which would tend to burst off pieces from the cliff face, and this process would be assisted by the drag exerted by the moving ice. However, these would only be auxiliary to the main thaw-freeze shattering, as the forces involved are small compared with those in frost action.

The writer has photographed such roches moutonnées in many widely different localities in Britain, Iceland, Norway and the Alps. Particularly instructive examples were examined in ice caves under Storjuvbræen in the Jotunheim. In places the rocks were streaming with melt water, whereas nearby the crevices in the rock were filled with ice. The evidence of disintegration by thawfreeze was certainly convincing. But in all these cases the shattered face was open to the atmosphere and so subject to atmospheric changes of temperature across the freezing point. Can such sapping operate under glaciers at depths below that at which pressure changes the ice from its more rigid to its more plastic state? Demorest has drawn attention to steps marked by striations, which he interpreted as indicating plastic flow down over the steps and into rock trenches. These features must therefore have been formed either when or before the ice lay thickly over the bedrock. Had they been formed long previously when the ice was thinner, one would hardly have expected to find the angles so well preserved.

It has already been remarked that there is no difficulty in providing limited quantities of melt water at the bottom of quite a thick glacier. Under thin glaciers and in the upper layers of thick glaciers the supply may indeed by very abundant as a result of surface melting. Ahlmann and Sverdrup ${ }^{5}$ have shown that even as far north as Spitsbergen only one-third of the surface melt water in summer is required to dissipate the winter cold wave and raise the temperature of the whole glacier to the pressure melting point. The remaining two-thirds is free to percolate downwards. In Iceland and western Norway, where the spring and summer rainfall greatly exceeds that in Spitsbergen and the temperature is higher, far greater quantities of melt water are available for percolation. Also in the Alps substantial rainfall and great radiation at high altitudes in relatively low latitudes combine to produce abundant melt water. Hughes and Seligman ${ }^{6}$ have made direct measurements of this melt water in the Jungfraufirn. The depth to which it penetrates is unknown. Dr. Carol ${ }^{7}$ has followed a melt-hole to a depth of approximately $73 \mathrm{~m}$. below the surface of one of the Grindelwald glaciers, a depth representing one-third of the total estimated thickness of the glacier at that point. The party was there held up by a dangerous constriction blocked at its lower end by a large water-filled basin. The time chosen for these investigations was November, when the water flow and snow to block the entrance would be at a minimum. On the other hand, at this time plastic collapse of the ice would be free to block such tunnels when they penetrate below the level at which the ice becomes plastic. In the spring and early summer, when large quantities of melt water would pour down these tunnels, they would probably be kept open to far greater depths.

Let us suppose that some melt water reached the bed of the glacier; it would then be most likely to maintain a tunnel open where the pressure of the ice was least. Dr. Carol's observations show that one place where this would be likely to occur would be immediately downstream from a roche moutonnée. The writer has noted a similar ice cave at the foot of a step in Snæfell, east Iceland, where an ice flow between $30 \mathrm{~m}$. and $60 \mathrm{~m}$. thick issued from an extinct crater into a cirque below. This all points to the fact that an ice mass of the order of $60 \mathrm{~m}$. thick possesses considerable strength, and, even when the thickness exceeds this amount and plastic flow becomes operative, the ice still possesses some strength. Otherwise it would be unable to grip rocks firmly enough to cause striations, although most striations are probably formed when the glaciers are thin enough for the ice to be in its rigid state throughout.

If there is such a tendency for ice to be melted away or otherwise removed from the lee sides of roches moutonnées and steps, then such localities may be subjected to atmospheric changes of temperature in a subdued form and some measure of thaw-freeze shattering may occur. The entry of cold air by these devious routes would seem to be very limited, and so the severity of thaw-freeze 
even at moderate depths in a glacier would be slight compared with that occurring at points where the rock bed is open to direct observation. But even if it occurred on a relatively small scale, it would help to account for the wide distribution of roches moutonnées and related forms on the floors of valleys which have been subjected to glaciation, and would imply that the mechanism envisaged by Dr. Carol might form a most important group of processes by which glaciers erode the valleys which they occupy.

\section{REFERENCES}

I. Matthes, F. Glaciers : Chapter 5 in Physics of the Earth-IX. Hydrology. Ed. by O. E. Meinzer, McGrawHill Book Co.; New York, I942.

2. Demorest, M. Ice Flow as revealed by Glacier Striation. Fourn. Geol. Vol. 46, 1938, pp. 700-25.

3. Seligman, G. The Structure of a Temperate Glacier. Geog. Fourn. Vol. 47, 194I, pp. $295^{-3}$ I 7.

4. Chamberlin, T. C. A Contribution to the Theory of Glacier Motion. Dec. Pubs. Univ. of Chicago, Vol. 9, 1904, pp. 193-206.

5. Sverdrup, H. U. Scientific Results of the Norwegian-Swedish Expedition, 1934. Part 3. The Temperature of the Firn on Isachsen's Plateau. Geografiska Annaler, Vol. 17, 1935, pp. 53-88.

6. Hughes, T. P., and Seligman, G. The Temperature, Melt Water Movement and Density Increase in the Névé of an Alpine Glacier. Mon. Not. Roy. Astron. Soc. Geophys. Supp. Vol. 4, 1939, pp. 616-47.

7. Seligman, G. A New Method of Glacier Examination. Fourn. Glaciology, Vol. 1, No. 1, 1947, p. 37.

\section{CORRESPONDENCE}

The Editors,

The Fournal of Glaciology

SIRS,

\section{Glacier Crevasses}

The point has been raised that my remarks in the discussion on the Extrusion Flow paper (fourn. Glaciology, Vol. r, No. r, r 947, p. I9), particularly my Figure 4, suggest that transverse crevasses may be formed without the need for a step in the glacier bed. I gather that the general view is that the presence of transverse crevasses indicates a step in the rock floor. This is a point of fundamental importance and it must be settled.

My own opinion is that transverse crevasses are not necessarily associated with steps in the bed, but that a step of any magnitude arising from differences between adjacent strata would produce significant crevasse systems. I regard the crevasse as indicating a zone of tension in the ice arising from the motion of the glacier contained within its more rigid rock boundaries, and I do not believe it is necessary to have steps in the bed to produce zones of tension.

If only we could find it possible to explore a glacier thoroughly throughout its length and depth, as we do as engineers when investigating landslips, by trenches and borings extending to the limits of movement, I believe many points of the above nature could be settled. Until some large investigation of this nature is undertaken our knowledge will always be severely restricted.

Building Research Station,

W. H. WARD

Watford, Herts.

\section{GLACIERIZATION AND GLACIATION}

THE drawings on the following pages were made by Dr. R. Streiff-Becker (Zürich) for one of the Editors in order to illustrate an article to be published elsewhere. They show the relationship between a glaciated area and the living glaciers which moulded it. A district covered by living glaciers is conveniently described as "glacierized." Wright and Priestley used this term in their Glaciology (p. 134), for land "inundated by ice" (German Vereist). It should prove valuable in antithesis to "glaciated." 